\title{
Severe acute respiratory syndrome coronavirus 2 reinfection in a coronavirus disease 2019 recovered young adult: a case report
}

\author{
Hussein Awada ${ }^{*}+\mathbb{D}$, Hasan Nassereldine ${ }^{\dagger}$ and Adel Hajj Ali $^{\dagger}$
}

\begin{abstract}
Background: Coronavirus disease 2019 has been a public health threat and a worldwide emergency for more than a year. Unfortunately, many questions concerning the pathophysiology, management, and long-term side effects remain unanswered, and novel aspects of the disease keep on emerging. Of concern to healthcare providers are the recent reported cases of reinfection. Serum coronavirus disease 2019 antibodies have been detected within a few days after onset of the disease. However, it remains unclear whether this immune response is universal, or whether it can lead to latent immunity.
\end{abstract}

Case presentation: A previously healthy 27 -year-old white man presented with fever, chills, back pain, and other constitutional symptoms, 2 days after being exposed to coronavirus disease 2019 positive patients. His severe acute respiratory syndrome coronavirus 2 polymerase chain reaction was positive, and his symptoms resolved over the next 2 weeks. One month after a confirmatory negative severe acute respiratory syndrome coronavirus 2 polymerase chain reaction, he was found to be ineligible for plasma donation as his anti-severe acute respiratory syndrome coronavirus 2 serology was negative. The patient redeveloped symptoms similar to his first infection 3 weeks after the negative serology test. He and his wife both tested positive via polymerase chain reaction. Their symptoms resolved over the next few days, and they had a negative polymerase chain reaction test 10 days after the positive polymerase chain reaction.

Conclusion: While studies showed that anti-severe acute respiratory syndrome coronavirus 2 immunoglobulins start to develop early after infection, our healthy young patient's immune system failed to mount latent immunity against the virus. This left him, especially amid widespread social and medical misconceptions, vulnerable to reinfection by severe acute respiratory syndrome coronavirus 2 . Our case disputes the timelines for immune response that were set and supported by research studies. Our case also raises questions regarding prioritizing vaccinating other individuals over those with prior infection.

Keywords: SARS CoV-2, COVID-19, Reinfection, Immune response

*Correspondence: hma86@mail.aub.edu

${ }^{\dagger}$ Hussein Awada, Hasan Nassereldine and Adel Hajj Ali contributed equally and are considered as first coauthors

Faculty of Medicine, American University of Beirut, Beirut, Lebanon

\section{Introduction}

Coronavirus disease 2019 (COVID-19), caused by the severe acute respiratory syndrome coronavirus 2 (SARSCoV-2), first appeared in Wuhan, China, in December 2019 [1]. Since then, COVID-19 has rapidly spread across the world, and it has been declared as a global original author(s) and the source, provide a link to the Creative Commons licence, and indicate if changes were made. The images or other third party material in this article are included in the article's Creative Commons licence, unless indicated otherwise in a credit line to the material. If material is not included in the article's Creative Commons licence and your intended use is not permitted by statutory regulation or exceeds the permitted use, you will need to obtain permission directly from the copyright holder. To view a copy of this licence, visit http://creativecommons.org/licenses/by/4.0/. The Creative Commons Public Domain Dedication waiver (http://creativeco mmons.org/publicdomain/zero/1.0/) applies to the data made available in this article, unless otherwise stated in a credit line to the data. 
pandemic by the World Health Organization (WHO) [1]. In Lebanon, the first case was documented on 21 February 2020 , and to date, more than 280,000 cases and 2300 deaths have been recorded [2,3]. While the majority of patients recover from COVID-19 worldwide, a growing concern about reinfection has been developing due to the increasing number of recovered patients who have been reported to have tested positive again $[4,5]$. Some of these reports have been contested as false positives, while others have been attributed to quick reexposure before a protective immune response has been mounted. Nevertheless, many studies did demonstrate that recovered COVID-19 patients do develop antibodies against SARSCoV-2 [6-8]. While there is no clear evidence whether all patients do develop protective latent immunity or how long may it last, several studies emphasized the improbability of reinfection due to a postinfection immunity that is at least short and temporary $[4,9,10]$. In this paper, we report a unique case of a patient, from Lebanon, who recovered from COVID-19 before getting reinfected with SARS-CoV-2 within 2 months of initial recovery.

\section{Case}

On 22 November 2020, a 27 -year-old white man developed a fever, measured orally as $40{ }^{\circ} \mathrm{C}(104 \mathrm{~F})$, in addition to chills, diffuse arthralgia, myalgia, headache, and back pain. His other vital signs were all within normal ranges [heart rate 69 beats per minute, blood pressure (BP) $118 / 76 \mathrm{mmHg}, \mathrm{SpO}_{2}$ 97\%]. He was previously healthy, with no history of smoking or alcohol intake, not on any medications, and with a family history that was negative for chronic diseases. He worked as a policeman. The patient had contact with two COVID19-positive patients and thus was instructed by his family physician to undergo a SARS CoV-2 real-time polymerase chain reaction (RT-PCR) after developing these symptoms. The patient was awake, alert, and oriented, and examination of the ears and throat showed no erythema or exudates in the tympanic membranes or tonsils. He had clear breath sounds bilaterally with no crackles, and cardiac auscultation suggested a regular rate and rhythm with no abnormal murmurs. He did not have any enlarged or painful lymph nodes. There were no other findings on physical and neurological examination. A nasopharyngeal swab was taken, and the PCR result came back positive. He underwent routine laboratory testing including complete blood count, fibrinogen, D-dimer, basic metabolic panel, and C-reactive protein, all of which were all within normal levels (red blood cells $4.5 \times 10^{6} / \mu \mathrm{L}$, hemoglobin $13.8 \mathrm{~g} / \mathrm{dL}$, white blood cells $6.69 \times 10^{3} / \mu \mathrm{L}$, fibrinogen $3.07 \mathrm{~g} / \mathrm{L}$, D-dimer $189 \mathrm{ng} / \mathrm{mL}$, creatinine $0.99 \mathrm{mg} / \mathrm{dL}$, sodium $137 \mathrm{mEq} / \mathrm{L}$, potassium $4.0 \mathrm{mEq} / \mathrm{L}$, C-reactive protein $3.7 \mathrm{mg} / \mathrm{L}$, ferritin $143.5 \mathrm{ng} / \mathrm{mL}$ ). However, a computed tomography $(\mathrm{CT})$ scan of the chest without contrast revealed the presence of mild emphysematous changes (Fig. 1). Accordingly, the patient was instructed to selfquarantine at his house. During the disease period, the patient developed watery diarrhea on day 4 and anosmia on day 6 . The fever subsided 3 days after symptom onset, and the patient was completely asymptomatic 8 days after the positive PCR with the exception of anosmia. The patient required only oral Panadol (paracetamol) $1000 \mathrm{mg}$ every 6 hours for pain and fever for 3 days. The patient never developed any cough or shortness of breath and, hence, is considered to have had a mild infection. On day 13 , the patient redid the PCR test, which turned out to be negative.

One month after the infection (26 December 2020), the patient's COVID serology was tested for the
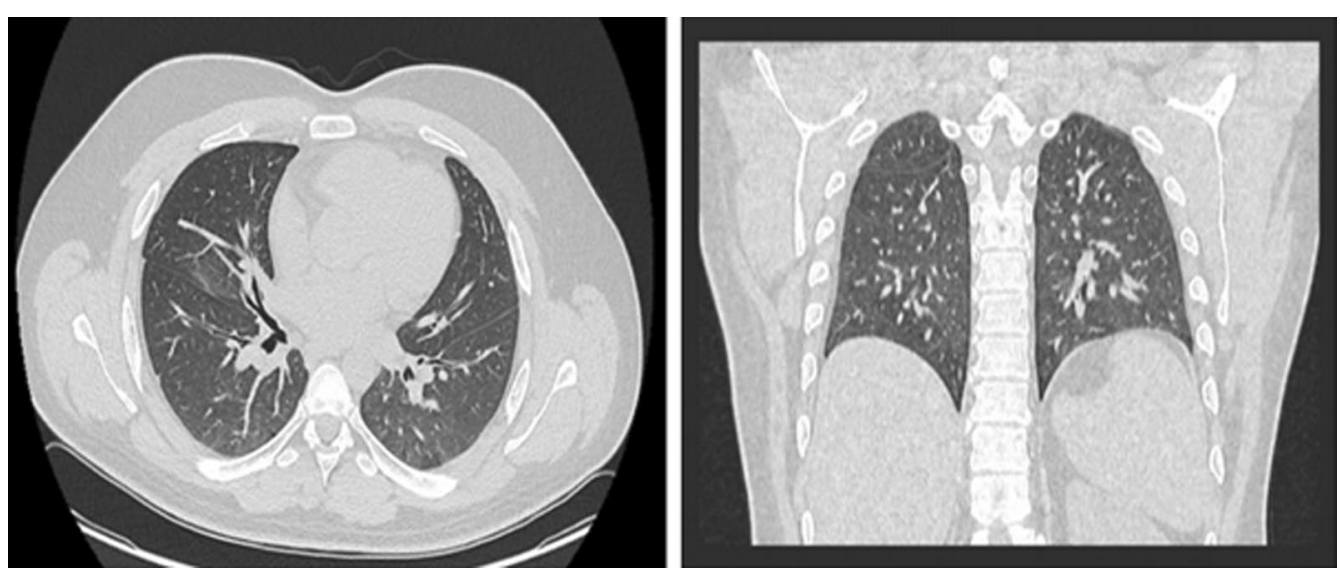

Fig. 1 Transverse and coronal sections CT scan of the chest showing emphysematous changes 
possibility of plasma donation. His anti-SARS-CoV-2 IgG levels were found to be low $(4.32 \mathrm{RU} / \mathrm{mL}$ ) (reference range: negative $<8$, borderline $8-11$, positive $>11 \mathrm{RU} / \mathrm{mL}$ ). He was informed that he did not develop sufficient immunity and so was unable to donate plasma.

On 17 January 2021, the patient developed fever again, and it was orally measured as $38{ }^{\circ} \mathrm{C}(100.4 \mathrm{~F})$. $\mathrm{He}$ also had a new headache. His heart rate was 68 beats per minute, blood pressure 121/72 $\mathrm{mmHg}$, and $\mathrm{SpO}_{2} 98 \%$. He was awake, alert, and oriented, and he had clear breath sounds over both of his lungs. The remainder of his physical and neurological examinations was normal. A day prior, the patient's wife had developed fever, chills, and diffuse myalgias. Both of them had contact with a confirmed COVID-19 patient a few days prior. The two individuals underwent SARS CoV-2 RT-PCR; both of them had positive tests, and they were instructed to self-quarantine at home. It should be noted that SARS-CoV-2 strain-specific PCR kits were not available in Lebanon at the time given the lack of widespread circulation of other strains in the country. The rapid influenza antigen and viral respiratory panel tests were negative in both patients. The patient's fever subsided 1 day after its onset without any antipyretic use. The patient repeated the PCR test 10 days after the last one, and it was found to be negative. He did not require any medications during the second infection. The timeline of the events up to this point is presented in Fig. 2.

The patient repeated the serum anti-SARS-CoV-2 IgG test on 22 February 2021, and the test came back positive this time $(38.4 \mathrm{RU} / \mathrm{mL})$. Hence, he was able to donate plasma this time.
The patient was last seen on 31 May 2021, and he reported being in good health since his last recovery. His physical examination was normal at the time.

\section{Discussion}

In contrast to the literature, our case represents a patient who was confirmed to have recovered from COVID-19 through a negative qRT-PCR test, did not generate sufficient COVID-19 immunoglobulin response by the first month postinfection, and was reinfected by SARS-CoV-2 2 months following his complete recovery. This case represents a challenge to the literature given the fact that our patient's immunoglobulin levels and the timing of the second positive qRT-PCR test do not match the viral shedding and immunoglobulin durations reported by the studies out there. Hence, it provides evidence that even healthy young adults may fail to mount a protective immune response against SARS-CoV-2 following recovery and thus, may be vulnerable to reinfection by the same virus. The occurrence of mild symptoms at both episodes in our patient is due to the general noninvasive pattern of the disease in the younger population. In such circumstances, the immune response may be faint, and hence, the patient may fail to develop sufficient immunity [8].

More than a year since the outbreak of COVID-19, there is still no consensus in the literature regarding the issue of reinfection with SARS-CoV-2. Yet, reports from around the world do show evidence that reinfection is indeed emerging [11-14]. The gold standard for the diagnosis of COVID-19 is via real-time reverse transcription polymerase chain reaction (RT-PCR) [1]. However, many reports of positive qRT-PCR tests recorded only a few days following confirmed recovery (via negative qRT-PCR tests or an appropriate isolation

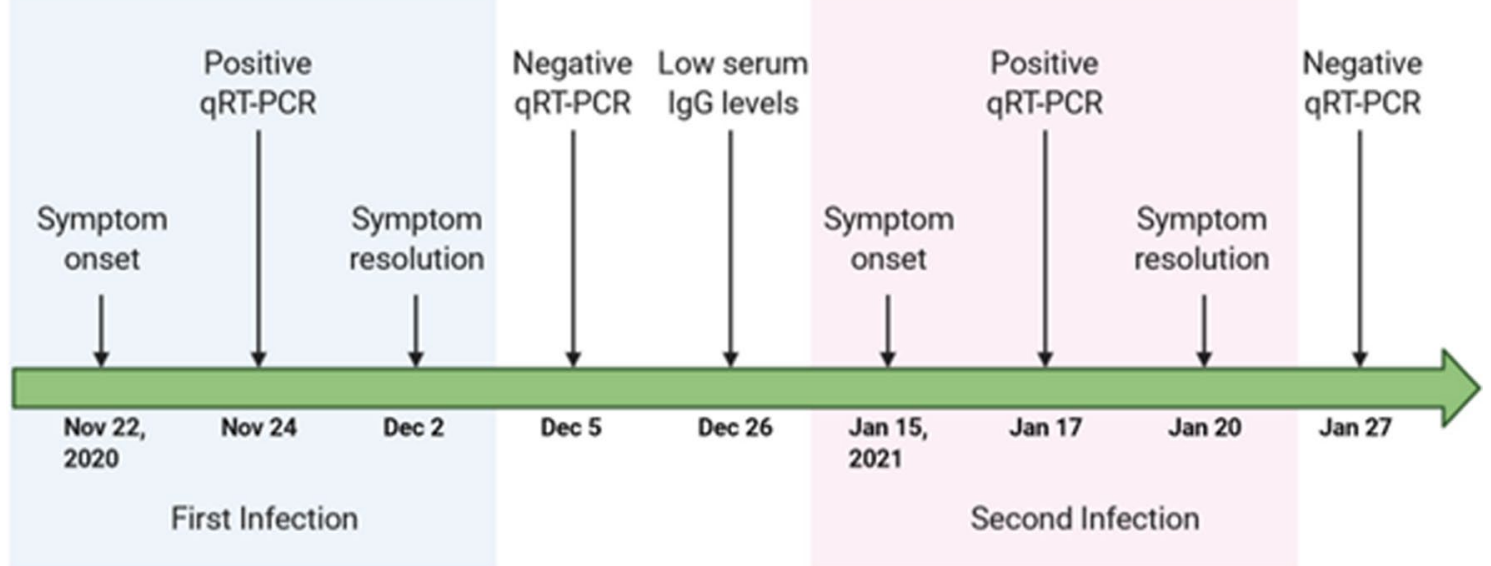

Fig. 2 Timeline of symptom onset, patient diagnosis, and recovery 
period) have been dismissed as not reinfection, rather being attributed to other possible explanations $[15,16]$. These explanations include (1) possible qRT-PCR false negatives at the time of discharge, (2) persistent viral shedding and increased replication because of early treatment discontinuation following clinical symptoms improvement, and (3) dead viruses and remnant genomic fragments [17-19].

What further increased the incredulity of dubious cases was that they presented quickly - within a few days-following recovery and short of the normal duration needed for the body to develop latent immunity [5]. In a study by Zhao et al., it was shown that COVID-19 IgM and IgG levels require a median of 12 and 14 days, respectively, following symptoms onset to become detectable in patients' blood [8]. Another study indicated that the COVID-19 antibodies and their protective effects could last about 40 days, after which there exists a possibility for reinfection [5]. Furthermore, studies showed that viral shedding lasts 8-37 days in general, with a median of 20 days [20]. While we acknowledge that viral shedding can last up to 3 months, with the longest recorded period in a survivor being 104 days, most studies have shown that persistent viral shedding beyond 1 month after symptom onset is extremely rare [21-25]. Thus, it would be extremely unlikely for our patient to have persistent shedding at the 2-month mark.

Genomic sequencing is the ultimate test that can distinguish between viral shedding and viral reinfection by the same/different strain [26]. Unfortunately, genomic testing for phenotypic characterization was not yet available in Lebanon. Nevertheless, the patient's wife did not develop symptoms until she was exposed to another COVID-19 patient, suggesting that her husband was also reinfected at that time rather than having viral shedding, which would have infected her much earlier. This narrative of reinfection is further reinforced by the fact that our patient was able to develop immunity only after the second episode. Moreover, at the time of the first infection, there was no evidence of the presence of a SARS$\mathrm{CoV}$ strain other than the original (first identified in Wuhan) circulating in Lebanon, and by the time of the second infection, only the Alpha variant (of Pango lineage B.1.1.7, identified first in the UK) was further recorded but to a very limited extent compared with the spread of the original strain $[27,28]$.

Further studies are needed to determine the factors that may hinder the immune system from mounting an adequate response to protect from subsequent SARS-CoV-2 reinfections. In addition, routine serologic screening of recovered patients may be of importance in stratifying the risk of reinfection by SARS-CoV-2 in these patients. This is especially important given the false impression held by some patients about the protective personal and public health measures being expendable after recovery, as well as the false belief that all recovered patients would not need to receive a SARS-CoV-2 vaccine afterwards.

\section{Conclusion}

SARS-CoV-2 reinfections remain to be fully clarified in the literature. This case shows that healthy young adults may fail to develop latent immunity and, as a result, could be prone to reinfection. Therefore, personal and public health protective measures remain of utmost importance. Additional research is also required to understand the immune response to this virus.

\section{Abbreviations}

COVID-19: Coronavirus disease 2019; SARS-CoV-2: Severe acute respiratory syndrome coronavirus 2; WHO: World Health Organization; qRT-PCR: Real-time quantitative reverse transcription polymerase chain reaction; IgG: Immunoglobulin G; IgM: Immunoglobulin M; CT: Computed tomography.

\section{Acknowledgements}

We would like to thank our patient for allowing us to share his case.

\section{Authors' contributions}

$\mathrm{HA}, \mathrm{HN}$, and $\mathrm{AH}$ contributed equally in providing patient care, manuscript writing, and preparing the attached figures. All authors read and approved the final manuscript.

Funding

No funding was received for this paper.

\section{Availability of data and materials}

Copies of SARS-CoV-2 PCR test results, laboratory tests, and the CT scan are available upon request by the Editor-in-Chief of this journal (not uploaded upon submission for confidentiality purposes).

\section{Declarations}

\section{Ethical approval and consent to participate}

Our paper is a case report in which a written informed consent for participation was obtained from the patient. Case reports do not meet the Department of Health and Human Services definition of research, and hence, this paper does not require review and approval by the IRB.

\section{Consent for publication}

A written informed consent was obtained from the patient for publication of this case report and any accompanying images. A copy of the written consent is available for review by the Editor-in-Chief of this journal upon request.

\section{Competing interests}

All authors declare no conflicting interests.

Received: 22 March 2021 Accepted: 16 June 2021

Published online: 16 July 2021

\section{References}

1. Almaghaslah D, et al. Review on the coronavirus disease (COVID-19) pandemic: its outbreak and current status. Int J Clin Pract. 2020;74(11): e13637. https://doi.org/10.1111/ijcp.13637.

2. Bizri AR, et al. COVID-19 pandemic: an insult over injury for Lebanon. J Commun Health. 2020;2:1-7. https://doi.org/10.1007/ s10900-020-00884-y. 
3. MOPH. Epidemiological surveillance program of COVID-19. https:// www.moph.gov.lb/en/Pages/2/24870/novel-coronavirus-2019. 2021

4. Meyerowitz-Katz G, Merone L. A systematic review and meta-analysis of published research data on COVID-19 infection fatality rates. IJID. 2020;101:138-48. https://doi.org/10.1016/j.ijid.2020.09.1464.

5. SeyedAlinaghi S, et al. Reinfection risk of novel coronavirus (COVID-19): a systematic review of current evidence. World J Virol. 2020;9(5):79-90. https://doi.org/10.5501/wjv.v9.i5.79.

6. Tian $\mathrm{X}$, et al. Potent binding of 2019 novel coronavirus spike protein by a SARS coronavirus-specific human monoclonal antibody. Emerg Microb Infect. 2020;9(1):382-5. https://doi.org/10.1080/22221751.2020.1729069.

7. Wu F, et al. Neutralizing antibody responses to SARS-CoV-2 in a COVID-19 recovered patient cohort and their implications. SSRN Elect J. 2020. https://doi.org/10.2139/ssrn.3566211.

8. Zhao J, et al. Antibody responses to SARS-CoV-2 in patients with novel coronavirus disease 2019. Clin Infect Dis. 2020;71(16):2027-34. https:// doi.org/10.1093/cid/ciaa344.

9. Gidari A, et al. Is recurrence possible in coronavirus disease 2019 (COVID19)? Case series and systematic review of literature. Eur J Clin Microbiol Infect Dis. 2021:40(1):1-12. https://doi.org/10.1007/s10096-020-04057-6.

10. Bao L, et al. Lack of reinfection in rhesus macaques infected with SARSCoV-2. Cold Spring Harbor Lab. 2020. https://doi.org/10.1101/2020.03.13. 990226.

11. Hanif M, Haider MA, Ali MJ, Naz S, Sundas F. Reinfection of COVID-19 in Pakistan: a first case report. Cureus. 2020;12(10): e11176. https://doi.org/ 10.7759/cureus.11176.

12. Mahallawi W. Case report: a recovered SARS CoV-2 patient protected from reinfection. Front Med. 2020;7: 564264. https://doi.org/10.3389/ fmed.2020.564264.

13. Torres DA, Ribeiro L, Riello A, Horovitz D, Pinto L, Croda J. Reinfection of COVID-19 after 3 months with a distinct and more aggressive clinical presentation: Case report. J Med Virol. 2020. https://doi.org/10.1002/jmv. 26637.

14. Iwasaki A. What reinfections mean for COVID-19. Lancet Infect Dis 2021;21(1):3-5. https://doi.org/10.1016/S1473-3099(20)30783-0.

15. Falahi S, Kenarkoohi A. COVID-19 reinfection: prolonged shedding or true reinfection? New Microbes New Infect. 2020;38: 100812. https://doi.org/ 10.1016/j.nmni.2020.100812

16. CDC (2020). Interim guidance on duration of isolation and precautions for adults with COVID-19. (n.d.). https://www.cdc.gov/coronavirus/2019ncov/hcp/duration-isolation.html. Accessed 15 Feb 2021

17 Tao W, et al. Re-detectable positive SARS-CoV-2 RNA tests in patients who recovered from COVID-19 with intestinal infection. Protein Cell. 2020;2:1-6. https://doi.org/10.1007/s13238-020-00778-8.

18. Wu F, Zhang W, Zhang L, Wang D, Wan Y. Discontinuation of antiviral drugs may be the reason for recovered COVID-19 patients testing positive again. Br J Hosp Med. 2020;81(4):1-2. https://doi.org/10.12968/ hmed.2020.0156.

19. Kang H, Wang Y, Tong Z, Liu X. Retest positive for SARS-CoV-2 RNA of "recovered" patients with COVID-19: persistence, sampling issues, or reinfection? J Med Virol. 2020;92(11):2263-5. https://doi.org/10.1002/jmv. 26114.

20. Zhou F, et al. Clinical course and risk factors for mortality of adult inpatients with COVID-19 in Wuhan, China: a retrospective cohort study. Lancet. 2020;395(10229):1054-62. https://doi.org/10.1016/S0140-6736(20) 30566-3.

21. Tirupathi R, Ramparas TR, Wadhwa G, Areti S, Kaur J, Salim S, Rabaan AA, Al-Tawfiq JA. Viral dynamics in the upper respiratory tract (URT) of SARSCoV-2. Infez Med. 2020;28(4):486-99 (PMID: 33257622).

22. To KK, Tsang OT, Leung WS, et al. Temporal profiles of viral load in posterior oropharyngeal saliva samples and serum antibody responses during infection by SARS-CoV-2: an observational cohort study. Lancet Infect Dis. 2020. https://doi.org/10.1016/S1473-3099(20)30196-1.

23. Lee PH, Tay WC, Sutjipto S, et al. Associations of viral ribonucleic acid (RNA) shedding patterns with clinical illness and immune responses in severe acute respiratory syndrome coronavirus 2 (SARS-CoV-2) infection. Clin Transl Immunol. 2020;9:e1160.

24. Zheng S, Fan J, Yu F, et al. Viral load dynamics and disease severity in patients infected with SARS-CoV-2 in Zhejiang province, China, JanuaryMarch 2020: retrospective cohort study. BMJ. 2020;369:1443.

25. Hao S, Lian J, Lu Y, et al. Decreased B cells on admission associated with prolonged Viral RNA shedding from the respiratory tract in coronavirus disease 2019: a case-control study. J Infect Dis. 2020;222:367-71.

26. To KKW, Hung IFN, Ip JD, Chu AWH, Chan WM, Tam AR, Fong CHY, Yuan S, Tsoi HW, Ng ACK, Lee LLY, Wan P, Tso EYK, To WK, Tsang DNC, Chan KH, Huang JD, Kok KH, Cheng VCC, Yuen KY. Coronavirus Disease 2019 (COVID-19) re-infection by a phylogenetically distinct severe acute respiratory syndrome coronavirus 2 strain confirmed by whole genome sequencing. Clin Infect Dis. 2020;1:1. https://doi.org/10.1093/cid/ciaa1 275.

27. Houssari N. First case of new COVID-19 strain found in Lebanon. 2020. https://www.arabnews.com/node/1782951/middle-east. Accessed 26 Apr 2021

28. World Health Organization. Tracking SARS-CoV-2 variants. World Health Organization. 2021. https://www.who.int/en/activities/tracking-SARSCoV-2-variants/.

\section{Publisher's Note}

Springer Nature remains neutral with regard to jurisdictional claims in published maps and institutional affiliations.
Ready to submit your research? Choose BMC and benefit from:

- fast, convenient online submission

- thorough peer review by experienced researchers in your field

- rapid publication on acceptance

- support for research data, including large and complex data types

- gold Open Access which fosters wider collaboration and increased citations

- maximum visibility for your research: over 100M website views per year

At BMC, research is always in progress.

Learn more biomedcentral.com/submissions 